\title{
PERLINDUNGAN HUKUM TERHADAP PEREMPUAN DALAM PROSES GUGAT CERAI (KHULU') DI PENGADILAN AGAMA PALEMBANG*
}

\author{
M. Syaifuddin dan Sri Turatmiyah \\ Fakultas Hukum Universitas Sriwijaya Palembang \\ Email : efka_turatmiyah@yahoo.com
}

\begin{abstract}
Divorce cases in the Islamic Court of Palembang (Pengadilan Agama Palembang) becomes the top of the list, during the year $2009(72 \%, 2010$ (72\%) and 2011 (in June) about 70\% The purpose of this study is to analyze the causes of high divorce rate happening in the city of Palembang, beside to explain the forms of legal protection and analyzes the factors that becoming obstacles for the wife in a filed divorced. The research was conducted with a Normative-Juridical approach which is completed with Empirical J uridical, The location is in the jurisdiction of the Islamic Courts in Palembang (Pengadilan Agama Palembang. Causes of high divorce cases in the city of Palembang, among others: a) economic factors; b) Lack of responsibility; c) a young age and no permanent employment; d) cheating and Unhealthy polygamy as well as domestic violence. Legal protection towards wives who filed the divorce, in Indonesian legal system has been arranged as equality in law and equal treatment before the law and the right to justice. Barriers toward the wife filing the divorce among others: cultural factors, economic dependence, lack of knowledge, and bias Perspective of judges who tend to blame the women, the long process of trial and expensive fees to be paid, also Over valued self-esteem in Indonesian people's community, as well as women's rights arenot easily executed.
\end{abstract}

Key words: legal protection, divorce process

\begin{abstract}
Abstrak
Kasus gugat cerai di Pengadilan Agama Palembang menempati urutan teratas, sepanjang tahun 2009 (72\%), 2010 (72\%) dan 2011 (bulan Juni) sebanyak 70\% Penelitian ini menganalisis mengenai penyebab tingginya gugat cerai yang terjadi di Kota Palembang, bentuk perlindungan hukum serta faktor yang menjadi hambatan bagi pihak istri dalam mengajukan gugat cerai. Metode pendekatan yang digunakan adalah yuridis normatif yang dilengkapi dengan yuridis empiris, dengan lokasi penelitian di wilayah hukum Pengadilan Agama Palembang. Berdasarkan hasil penelitian, penyebab tingginya kasus gugat cerai di Kota Palembang antara lain: faktor ekonomi; tidak ada tanggung jawab; usia muda dan tidak ada pekerjaan tetap; selingkuh dan poligami tidak sehat serta KDRT. Perlindungan hukum terhadap istri yang mengajukan gugat cerai, sebagaimana sistem hukum Indonesia sudah mengatur persamaan kedudukan dalam hukum dan perlakuan yang sama di depan hukum dan hak memperoleh keadilan. Hambatan pihak istri menga-jukan gugat cerai antara lain: faktor budaya, ketergantungan ekonomi, pengetahuan yang minim, perspektif hakim yang bias dan cenderung menyalahkan pihak perempuan, proses sidang yang lama dan biaya yang harus dibayar, harga diri dalam kehidupan masyarakat, serta hak-hak perempuan yang tidak mudah dieksekusi.
\end{abstract}

Kata kunci: perlindungan hukum, gugat cerai.

\section{Pendahuluan}

Perkawinan sebagaimana diatur dalam ketentuan Pasal 1 UU No. I Tahun 1974 Tentang Perkawinan Selanjutnya disebut UU Perkawin-

* Tulisan ini merupakan ringkasan Hasil Penelitian Hibah Fundamental DP2M T.A 2011 dengan kontrak No. 168/ UN9. 3. 1/ PL/ 2011 tanggal 15 April 2011 an) adalah ikatan lahir bathin antara seorang pria dengan seorang wanita sebagai suami istri dengan tujuan membentuk keluarga (rumah tangga) yang bahagia dan kekal berdasarkan Ketuhanan Yang Maha Esa. Hubungan antara suami istri adalah inti atau merupakan masalah pokok dalam hubungan antara sesama manusia 
sebagai individu, manusia sebagai makhluk sosial (zoonpoliticon) manusia humosacra humini sebagaimana dinyatakan Aristoteles. Hubungan suami istri tersebut dalam Hukum Islam haruslah dilandasi dengan unsur makruf, sakinah, mawadah dan rahmah. Makruf artinya pergaulan antara suami istri harus saling hormat menghormati, saling menjaga rahasia masing-masing. Sakinah dimaksudkan sebagai penjabaran lebih lanjut dari makruf yaitu agar suasana kehidupan dalam rumah tangga suami istri terdapat keadaan yang aman dan tenteram, tidak terjadi silih sengketa atau pertentangan pendapat yang prinsipal.

Ketentuan Pasal 38 UU Perkawinan mengatur bahwa putusnya perkawinan dapat terjadi karena kematian, perceraian dan atas keputusan pengadilan. Pengaturan tersebut mempunyai pengertian bahwa perceraian harus didahului dengan adanya gugatan perceraian yang diajukan ke Pengadilan, setelah pengadilan yang bersangkutan berusaha dan tidak berhasil mendamaikan kedua belah pihak. Perceraian disyaratkan harus ada cukup alasan bahwa antara suami istri tidak akan hidup rukun sebagai suami istri. Ditegaskan bahwa putusnya perkawinan dapat dilakukan melalui talaq maupun cerai. Talaq diterjemahkan ke dalam bahasa Indonesia berarti putusnya perkawinan antara suami istri (cerai). Peraturan Menteri Agama No. 3 Tahun 1975 Pasal 28 dan 30 membedakan talaq dan cerai. Talaq adalah pemutusan hubungan perkawinan atas permohonan suami, sedangkan cerai gugat (khulu') pemutusan hubungan perkawinan yang didahului gugatan dari pihak istri (Pasal 39 ayat (2) UU Perkawinan).

Khulu' atau talak tebus adalah talak yang diucapkan oleh suami dengan pemba-yaran dari pihak istri kepada suami. Khulu' atau lebih populer dengan istilah gugat cerai terjadi dari kehendak atau kemauan pihak istri. Kasus gugat cerai di Pengadilan Agama (PA) Palembang, Sumatera Selatan menempati urutan teratas, yakni sepanjang tahun 2009 sebanyak 72\% tahun 2010 seba-nyak 72\% dan bulan J uni 2011 seba- nyak $70 \%$ sedangkan kasus cerai talak menempati urutan kedua. ${ }^{1}$

Kondisi sekarang jauh berbeda dengan masa beberapa tahun lalu. Ketika itu suami istri khususnya istri akan memilih sikap bertahan demi keutuhan keluarganya apapun masalah yang sedang dihadapi. Saat ini sering terjadi bentuk kekerasan dalam rumah tangga yang dilakukan pihak suami terhadap istri, bahkan tidak jarang istri dibunuh akibat permasalahan rumah tangganya. Hasil studi menunjukkan bahwa tindak kekerasan terhadap istri terjadi hampir pada semua masyarakat. Adapun bentuk tindak kekerasan khususnya terhadap perempuan di dalam lingkup rumah tangga, meliputi: kekerasan fisik, psikis, seksual serta penelantaran rumah. ${ }^{2}$

Masalah kekerasan terhadap perempuan saat ini tidak hanya merupakan masalah individual atau masalah nasional, tetapi sudah merupakan masalah global. Banyak istilah digunakan seperti "violence against woman, gender bassed violence, gender violence, female focussed violence, domestic violence" dan sebagainya. ${ }^{3}$ Seiring perubahan nilai-nilai sosial dan semakin banyak perempuan yang sadar akan hak-hak dan kewajibannya, maka perempuan sebagai istri tidak tinggal diam dan tidak mau diperlakukan sewenang-wenang oleh laki-laki, maka pihak perempuan akan menggunakan haknya dengan mengajukan gugat cerai ke pengadilan. Kondisi ini jelas jauh berbeda dengan masa beberapa tahun lalu, di mana suami istri, khususnya pihak istri, akan memilih sikap bertahan demi keutuhan keluarganya apapun masalah yang dihadapi.

Indonesia telah banyak melakukan ratifikasi terhadap perjanjian internasional, salah satunya adalah Convention on the Elimination of All Forms of Discrimination Against Women (CEDAW) yang diterjemahkan sebagai Pengha-

Data diambil dari Pengadilan Agama Palembang tanggal 20 September 2011.

2 AM. Mujahidin, "Penghapusan Kekerasan Dalam Rmah Tangga (KDRT) Ruang Lingkup Perlindungan Terhadap Anak dan Istri", Varia Peradilan Majalah Hukum, Tahun XXV No. 290, J anuari 2010, Jakarta: Ikahi, hlm. 73.

3 Muladi yang dikutip dari A. Reni Widyastuti, "Peran Hukum Dalam Memberikan Perlindungan terhadap Perempuan dari Tindak Kekerasan di Era Globalisasi", Jurnal Mimbar Hukum, Tahun 2010, Yogyakarta: FH UGM, hlm. 395. 
pusan Segala bentuk diskriminasi terhadap Perempuan dengan UU No. 7 Tahun 1984 tentang Pengesahan Konvensi mengenai Penghapusan Segala Bentuk Diskriminasi terhadap Perempuan. Hal ini dilakukan pemerintah sebagai wujud pelak-sanaan terhadap amanat UUD 1945 Pasal 27 dan Pasal 31 UU Perkawinan tentang Perkawinan yang merumuskan bahwa hak dan kedudukan istri adalah seimbang dengan hak dan kedudukan suami dalam kehidupan rumah tangga dan pergaulan hidup bersama dalam masyarakat. Oleh karena itu, segala bentuk diskriminasi terhadap perempuan wajib dihapuskan karena tidak sesuai dengan falsafah hidup bangsa. Beberapa ketentuan undang-undang tersebut mengatur tentang hak-hak perempuan dan diperkuat lagi dengan diberlakukannya UU No. 23 Tahun 2004 Tentang Penghapusan Kekerasan Dalam Rumah Tangga (selanjutnya disebut UU KDRT) sebagai bentuk kepedulian negara melindungi hak-hak perempuan sebagai warga negara.

\section{Permasalahan}

Berdasarkan latar belakang tersebut diambil permasalahan dalam penelitian ini yaitu faktor apakah yang menyebabkan tingginya gugat cerai di Kota Palembang, bagaimana bentuk perlindungan hukum terhadap pihak istri dan faktor apa yang menjadi hambatan bagi pihak istri dalaam mengajukaan gugat cerai di pengadilan.

\section{Metode Penelitian}

Peneltian ini menggunakan 2 (dua) metode penelitian yang berbeda yaitu penelitian hukum normatif dan penelitian socio-legal. Penelitian hukum normatif dilakukan untuk mengidentifikasikan konsep dan asas-asas hukum yang digunakan tentunya yang berkaitan dengan topik permasalahan. ${ }^{4}$ Pendekatan penelitian digunakan beberapa pendekatan, yaitu pendekatan peraturan perundangan (Statute Approach) dan pendekatan kasus (Case Approach). Pendekatan statuta terutama ditekankan

Johny Ibrahim, 2008, Teori \& Metodologi Penelitian Hukum Normatif, Malang: Bayu Media Publishing, hlm. 443. dalam penela-ahan UU No.1 Tahun 1974, PP No. 9 Tahun 1975, UU No. 23 Tahun 2004, dan UU No. 39 tahun 1999 serta konvensi CEDAW. Pendekatan kasus bertujuan untuk mempelajari penerapan norma-norma atau kaidah hukum yang dalam praktik hukum, terutama mengenai kasus gugat cerai yang telah diputus dalam wilayah hukum Pengadilan Agama Palembang, sebagaimana yang dapat dilihat dalam yurisprudensi terhadap perkara-perkara yang menjadi fokus penelitian. Kasus-kasus yang telah mempunyai kekuatan hukum tetap, bermakna empiris, namun dalam penelitian hukum normatif, kasus-kasus tersebut dipelajari untuk memperoleh gambaran terhadap dampak dimensi penormaan dalam suatu aturan hukum dalam praktik hukum, serta menghasilkan analisis untuk bahan masukan (input) dalam eksplanasi hukum. ${ }^{5}$ Sumber data utama adalah data sekunder dengan didukung data primer.

\section{Pembahasan. \\ Profil Wilayah Hukum Pengadilan Agama Kota Palembang}

Kota Palembang sebagai salah satu kota besar di Indonesia yang merupakan Ibu Kota Provinsi Sumatera Selatan. Palembang merupakan kota terbesar kedua di Sumatera setelah Medan. Kota Palembang pada mulanya menjadi pusat Kerajaan Sriwijaya, sebelum kemudian berpindah ke Jambi. Bukit Siguntang di bagian barat kota Palembang sampai saat ini masih dikeramatkan banyak orang dan dianggap sebagai bekas pusat kesucian di masa lalu. Palembang merupakan kota tertua di Indonesia, berdasarkan prasasti Kedukan Bukit, yang ditafsirkan sebagai kota yang merupakan ibukota Kerajaan Sriwijaya pada tanggal 16 Juni 682 Masehi dan sampai sekarang tanggal tersebut menjadi patokan hari lahir Kota Palembang. Luas wilayah Kota Palembang adalah 102, 47 $\mathrm{Km}^{2}$ dengan ketinggian rata-rata 8 meter dari permukaan laut. Letak Palembang cukup strategis karena dilalui oleh Jalan Lintas Sumatera yang menghubungkan antara daerah di Pulau Sumatera. Kota Palembang terdapat Sungai Mu-

lbid., hlm. 321. 
si yang dilintasi jembatan Ampera, berfungsi sebagai sarana transportasi dan perdagangan antar wilayah.

Pada bulan November 1951, atas perintah Kementerian Agama melalui biro Peradilan Agama Pusat, Pengadilan Agama ini dibekukan. Sebagai gantinya Kementerian Agama mengaktifkan kembali secara resmi Pengadilan Agama Palembang sebagai lanjutan Raad Agama Palembang dengan Penetapan Menteri Agama No. 15 Tahun 1952 dengan Kiagus Haji Nangtoyib sebagai ketuanya, ini sebagai Pengadilan Agama pertama di Sumatera. Sebagai realisasi dari PP No. 45 Tahun 1957 Tentang Pengadilan Agama/ Mahkamah Syar'iyah di luar J awa dan Madura, pada tanggal 31 November 1957 Menteri agama mengeluarkan Penetapan Nomor 58 Tahun 1957 tentang Pembentukan Pengadilan Agama/Mahkamah Syar'iyah di Sumatera. Dengan demikian di Palembang dibentuk sebuah Pengadilan Agama yang mempunyai daerah hukum meliputi Kota Palembang. Keadaan Pengadilan Agama Palembang sesudah berlakunya UU Perkawinan, secara umum relatif lebih baik dari sebelumnya. Keadaan personil dan peralatan kantor dari tahun ke tahun sudah mulai diperhatikan, begitu juga volume perkara meningkat rata-rata 40 perkara menjadi 60 perkara dalam setiap bulan. Sejak tanggal 12 November 2009 Pengadilan Agama Palembang dipimpin oleh Drs. H. Burdan Burniat, S.H sebagai Ketua, dan Drs. Asri Damsy, S.H sebagai Wakil Ketua. ${ }^{6}$ Sementara jenis perkara yang masuk dan diputus di Pengadilan Agama Palembang berdasarkan urutan banyaknya perkara yang masuk antara lain: cerai gugat, cerai talak, pengesahan nikah, penetapan waris, izin poligami dan lain-lain. ${ }^{7}$

\section{Faktor-faktor Penyebab Tingginya Gugat Ce- rai di Kota Palembang}

Setiap pasangan yang menikah mengharapkan perkawinannya akan langgeng sampai akhir hayat, begitu juga yang menjadi harapan

\footnotetext{
6 Hasil wawancara dengan Drs. M. Sukri, S.H Hakim Pengadilan Agama Palembang tanggal 22 September 2011.

7 Data diambil dari Pengadilan Agama Palembang tanggal 22 September 2011.
}

agama dan ketentuan peraturan perundangan yang mengatur tentang perkawinan. Namun demikian, terdapat pasangan yang mengalami kendala dan persoalan yang tidak dapat diatasi kehidupan rumah tangga mereka sehingga kebersamaan tidak lagi mendatangkan kebahagiaan, akan tetapi sebaliknya mendatangkan penderitaan yang tidak berujung. Berkaitan dengan hal tersebut, ajaran agama Islam dan UU Perkawinan mengatur jalan keluar dari persoalan itu. Istri, apabila mengakibatkan kesulitan dan tidak ada jalan keluar yang lain bagi suami, maka suami dibolehkan menceraikan istrinya, sebaliknya apabila istri tidak tahan lagi menanggung derita karena suaminya, istri dibolehkan mengajukan gugatan cerai terhadap suaminya. Kewajiban memberikan nafkah kepada istri dan anak-anak, tidak hanya berlaku sewaktu masih terikat dalam perkawinan. Suami masih berkewajiban untuk menafkahi mereka sekalipun telah terjadi perceraian. Istri wajib diberi nafkah layak sesuai dengan standar kehidupan standar. ${ }^{8}$

UU Perkawinan mengatur hak yang sama untuk mengajukan perceraian bagi suami mau pun istri. Dalam Kompilasi Hukum Islam (selanjutnya disebut $\mathrm{KHI}$ ) Pasal 114 mengatur bahwa putusnya perkawinan disebabkan perceraian dapat karena talak atau berdasarkan gugatan perceraian. Perceraian karena talak maupun gugat cerai, hanya dapat dilakukan di depan sidang Pengadilan Agama.

Alasan perceraian, baik karena cerai talak maupun cerai gugat diatur dalam Pasal 116 $\mathrm{KHI}$, sebagai berikut:

a. apabila salah satu pihak berbuat zina atau menjadi pemabuk, pema-dat, penjudi dan lainnya yang sukar disembuhkan;

b. salah satu pihak meninggalkan yang lain selama 2 (dua) tahun berturutturut tanpa izin pihak lain dan tanpa alasan yang sah atau karena hal lain di luar kemampuannya;

\footnotetext{
8 Hartini dan Destri Budi Nugraheni, "Studi tentang Pemutusan Hak-Hak Isteri Olah Suami Yang Menikah Menurut Hukum Islam Di Daerah Istimewa Yogyakarta", J urnal Mimbar Hukum, No. 42/ X/2002, Tahun 2002, Yogyakarta: Fakultas Hukum UGM, hlm. 55.
} 
c. salah satu pihak mendapat hukuman penjara 5 (lima) tahun atau hukum-an yang lebih berat setelah perka-winan berlangsung;

d. salah satu pihak melakukan kekejaman atau penganiayaan berat yang membahayakan pihak lain;

e. salah satu pihak mendapat cacat badan atau penyakit yang mengakibatkan tidak dapat menjalankan kewajibannya sebagai suami/ istri;

f. antara suami istri terus menerus terjadi perselisihan dan pertengkar-an dan tidak ada harapan akan hi-dup rukun lagi dalam rumah tangga;

g. suami melanggar ta'lik talak;

h. peralihan agama atau murtad yang menyebabkan terjadinya ketidakrukunan dalam rumah tangga.

Berdasarkan hasil penelitian, kasus gugat cerai di Pengadilan Agama Palembang dapat disaj ikan pada tabel berikut ini: ${ }^{9}$

Tabel 1: Kasus Gugat Cerai di PA Palembang

\begin{tabular}{|c|c|c|c|c|c|}
\hline No. & Tahun & $\begin{array}{c}\text { Cerai } \\
\text { talak } \\
\text { diterima }\end{array}$ & $\begin{array}{c}\text { Cerai } \\
\text { gugat } \\
\text { diterima }\end{array}$ & $\begin{array}{c}\text { Cerai } \\
\text { talak } \\
\text { diputus }\end{array}$ & $\begin{array}{c}\text { Cerai } \\
\text { gugat } \\
\text { diputus }\end{array}$ \\
\hline 1. & 2009 & 379 & 946 & 283 & 737 \\
2. & 2010 & 415 & 1065 & 291 & 831 \\
3. & 2011 & 652 & 1479 & 141 & 511 \\
& (J uni) & & & & \\
\hline
\end{tabular}

Tingginya tingkat perceraian terjadi karena adanya perubahan nilai-nilai sosial yang sedang terjadi di tengah masyarakat Indonesia umumnya dan di Kota Palembang khususnya, bahkan akibat kemampuan ekonomi yang terus meningkat di kalangan kaum perempuan, ikut mempengaruhi tingginya gugat cerai yang diajukan istri terhadap suami. ${ }^{10}$ Ketua Umum Pimpinan Pusat Nasyiatul Aisyiyah, Evi Sofia Inayati, menyadari bahwa perceraian ini bukanlah masalah baru. Namun yang membuatnya prihatin, kasus perceraian terus meningkat seiring dengan perubahan zaman. Perubahan nilai-nilai sosial yang sedang terjadi di masyarakat Indonesia membuat tingkat perceraian semakin tinggi, bahkan akibat kemampuan ekonomi yang terus meningkat di kalangan kaum hawa ikut mempengaruhi tingginya kasus gugat cerai. Seiring pe-

9 Data Pengadilan Agama Palembang yang diambil pada tanggal 20 September 2011.

10 Kasus Perceraian Meningkat, tersedia di website http:// www. nasyiah.or.id diakses tanggal 5 Mei 2011. rubahan nilai-nilai sosial tersebut, sangat mengejutkan ketika tingkat gugat cerai yang diajukan istri terhadap suami jauh lebih tinggi. Kenyataan ini terjadi karena kemampuan ekonomi dari kaum perempuan terus membaik. ${ }^{11}$

Dini P. Daengsari mengakui adanya perubahan sosial masyarakat Indonesia yang membuat angka perceraian dewasa ini meningkat tajam. Banyaknya perempuan yang bekerja membuat mereka kini tidak lagi banyak tergantung pada laki-laki. Perempuan, sekarang berani hidup sendiri, berbeda dengan dahulu ketika perempuan lebih banyak bergantung kepada laki-laki. ${ }^{12}$ Berdasarkan hasil wawancara, ${ }^{13}$ pada saat ini terjadi perubahan situasi, karena biasanya suami yang menggugat istri, sekarang istri yang menggugat suami. Hal demikian dapat saja terjadi karena pengaruh kehidupan sosial, misalnya infotainment/ media massa. Hal ini memunculkan fenomena yang menimbulkan penafsiran bahwa pihak perempuan telah memiliki kesadaran cukup tinggi dalam menuntut hak kepada suami. Mereka tidak ingin seterusnya dijadikan sub ordinat yang hanya menerima sesuai keinginan suami.

Pengaruh gender atau meningkatnya pengetahuan hukum perempuan merupakan potensi besar yang memotivasi istri berani mengajukan cerai gugat. Kaum perempuan saat ini memiliki pemikiran lebih kritis karena mereka sudah biasa dan mudah mendapatkan semua informasi hak-hak perempuan dalam kaitan dengan perkawinan. Hak untuk mengajukan cerai kepada suami istri dalam ranah hukum memberi peluang bagi kaum perempuan memperoleh kehidupan yang lebih baik. Perempuan sebagai istri mempunyai hak yang sama untuk mendapatkan perlindungan dan kehidupan yang layak. Alasan inilah yang umumnya melatarbelakangi istri mengajukan gugat cerai ke Pengadilan Agama. ${ }^{14}$

\footnotetext{
11 Ibid.

12 Ibid.

13 Hasil wawancara dengan Drs. M. Sukri, S.H., Hakim Pengadilan Agama Palembang tanggal 22 September 2011.

14 Data dari Pengadilan Agama Palembang, diambil tanggal 20 September 2011.
} 
Ada beberapa faktor penyebab gugat cerai di Pengadilan Agama Palembang. Pertama, faktor ekonomi dan kurangnya tanggung jawab. Perubahan sosial mempengaruhi pola hidup seseorang, sehingga tuntutan akan kebutuhan rumah tangga mengalami perubahan. Suami, dalam keadaan kurang memberikan tanggung jawabnya sebagai kepala rumah tangga dan tidak memikirkan kebutuhan akan istri dan anaknya, serta istri merasa mampu untuk hidup sendiri, maka istri cenderung memilih cerai dari suami. Kedua, usia muda dan tidak ada pekerjaan tetap. Faktor usia menjadi salah satu penyebab terjadinya gugat cerai. Usia yang belum matang dalam mengarungi rumah tangga, didukung juga belum mempunyai penghasilan yang tetap. Fenomena perkawinan usia muda atau di bawah umur telah "menampar" wajah pembuat hukum dan aparat hukum di negeri ini. Praktek perkawinan di bawah umur mengindikasikan bahwa hukum perkawinan Indonesia nyaris seperti hukum yang "tak bergigi", karena terjadi pelanggaran hukum perkawinan tanpa dapat ditegakkan secara hukum. ${ }^{15}$ Berkaitan dengan batasan usia perkawinan, ini merupakan hal sensitive sifatnya, karena disebabkan sangat erat kaitannya dengan permasalahan setuju atau tidaknya seseorang untuk dinikahkan. Perlu adanya ketentuan batas umur, hal ini didasarkan pada pertimbangan tentang kemaslahatan keluarga dan rumah tangga yang dibentuk dalam suatu ikatan perkawinan. Calon suami maupun istri yang akan atau hendak melangsungkan perkawinan harus telah "masak" jiwa dan raganya agar dapat mewujudkan tujuan perkawinan secara baik tanpa harus berakhir dengan perceraian serta dapat menghasil-kan keturunan yang baik dan sehat. ${ }^{16}$

Ketiga, selingkuh dan poligami tidak se-

hat. Perselingkuhan yang dilakukan suami membuat istri kehilangan kepercayaannya dan upaya untuk kembali mempercayai suami men-

15 Supriyadi dan Yulkarnain Harahap, "Perkawinan Di Bawah Umur Dalam Perspektif Hukum Pidana dan Hukum Islam", J urnal Mimbar Hukum, Vol. 21 No. 3, Oktober 2009, Yogyakarta: Fakultas Hukum UGM, hlm. 591.

16 Ramlan Yusuf Rangkuti, "Pembatasan Usia kawin Dan Persetujuan Calon Mempelai Dalam perspektif Hukum Islam", J urnal Hukum Equality, Vol. 13 No. 1, Februari 2008, Medan: Fakultas Hukum USU, hIm. 66 jadi masalah yang paling menyita waktu sepanjang hidup. Kepercayaan yang hilang tampaknya sulit dikembalikan lagi, ditambah perasaan sakit karena telah dikhianati akhirnya membuat istri memilih bercerai.

Keempat, KDRT. Faktor penyebab terjadinya KDRT secara umum adalah budaya patriarki yang masih kuat sehingga laki-laki dianggap paling dominan, baik di dalam rumah tangga maupun di luar rumah tangga. Himpinan ekonomi keluarga, himpitan masalah kota besar yang mendorong stress, kondisi lingkungan dan pekerjaan yang berat mendorong temperamental orang. ${ }^{17}$ KDRT merupakan segala bentuk penganiayaan, baik yang berupa penyiksaan fisik, psikis/emosi, seksual maupun ekonomi. Pada kasus KDRT, para wanita ditempatkan sebagai korban, namun sebenarnya tanpa sadar pihak perempuan memilih tetap menjadi korban karena berbagai alasan. Keberanian untuk tidak menjadi korban suami terus menerus yanag membuat istri berani mengambil tindakan drastis, yaitu meninggalkan suaminya dan menggugat cerai.

Setelah adanya UU KDRT, dalam implementasinya, difokuskan seperti kepada kesetaraan dalam pendidikan, pelaksanannya. Ketentuan Pasal 4 ayat (100) CEDAW temporary special measure menekankan bahwa perempuan harus diberdayakan untuk memanfaatkan potensi yang ada. Bukan hanya fisik dan intelektual tetapi social cultural juga termasuk lingkungan dan orang tua. State obligation (tanggung jawab negara) termasuk judicial system (system peradilan) yang juga harus menjamin equality (keadilan). ${ }^{18}$

Hukum sebagai alat untuk membangun masyarakat (law as a tool os social engineering) digunakan sebagai dasar dari apllied theory. Hukum dan ekonomi merupakan dua sistem dari sistem kemasyarakatan yang sering berin-

17 Gusliana, "Penyebab Terjadinya Kekerasan Dalam Rumah Tangga (KDRT) Yang Dilakukan Oleh Suami Terhadap Istri di Kota Pekanbaru", J urnal IImu Hukum, Edisi I No. I, Agustus 2010, Riau: Fakultas Hukum Universitas Riau, hlm. 62.

18 Sjamsiah Ahmad, 2010, Tentang Gerakan Perempuan dan CEDAW di Indonesia, Jakarta: Komnas Perempuan Edisi 4 maret, hlm. 7. 
tegrasi satu dengan yang lain. ${ }^{19}$ Ditegaskan oleh Satjipto Rahardjo bahwa berlakunya aturan hukum secara efektif setidaknya diperlukan keserasian antara hukum atau peraturan itu sendiri, mentalitas pelaksana hukum, fasilitas pendukung pelaksana hukum serta kesadaran hukum, kepatuhan hukum dan perilaku masyarakat. $^{20}$

\section{Bentuk Perlindungan Hukum bagi Pihak Istri dalam Proses Gugat Cerai}

Perlindungan merupakan suatu hal atau perbuatan untuk melindungi subjek hukum berdasarkan peraturan perundangan yang berlaku disertai dengan sanksi-sanksi apabila ada yang melakukan wanprestasi. Perlindungan hukum juga merupakan jaminan hak-hak dan kewajiban manusia dalam rangka memenuhi kepentingan sendiri maupun di dalam hubungan dengan manusia lain. ${ }^{21}$

Sifat manusia, cenderung ingin kepentingannya dipenuhi terlebih dahulu, tanpa mengingat kepentingan orang lain dan tidak jarang terjadi kepentingan-kepentingan saling bertentangan. Keadaan tersebut, apa-bila tidak diatur atau tidak dibatasi, maka yang lemah akan tertindas atau setidak-tidaknya timbul pertentangan atau gejolak. Berkaitan dengan perlindungan hukum, maka keadilan dan kepastian hukum yang harus diberikan kepada seseorang manakala orang tersebut memerlukan perlindungan. Hukum senantiasa berhubungan dengan masyarakat. Dalam masyarakat sering terjadi konflik, oleh sebab itu diperlakukan suatu atur-an untuk mengatur kepentingan antara manusia dalam masyarakat. Sesuai dengan teori konflik yang menekankan bahwa setiap masyarakat merupakan subjek dari perubahan sosial dan perubahan itu ada dimana-mana. Pendapat Gustav Radburch seorang Filsuf J erman menyatakan bahwa ada 3 (tiga) ide dasar hukum se-

19 H.M. Abdi Koro, "Tinj auan Hukum Atas Perkawinan Dini dikaitkan dengan Perlindungan Hukum terhadap Anak Di Bawah Umur dalam Upaya Pengembangan Kualitas Sumber Daya Manusia", Varia Peradilan Majalah Hukum, Tahun XXV No. 2391, Tahun 2010, Jakarta: Ikahi, hlm. 40.

20 Satjipto Rahardjo dalam H.M. Abdi Koro, Ibid, hlm. 41.

21 Sudikno Mertokusumo, 1991, Mengenal Hukum (Suatu Pengantar), Yogyakarta: Liberty, hlm.. 9. bagai tujuan hukum yaitu keadilan, kemanfaatan, dan kepastian hukum. Urutan tersebut sesuai dengan prioritas tujuan hukum.

Hukum yang berisi kaidah-kaidah atau aturan adalah untuk menjamin adanya kepastian hukum. Pemahaman akan kaidah-kaidah hukum tersebut, maka masyarakat akan menyadari bahwa kehidupan bersama akan tertib apabila terwujud kepastian dalam hubungan antara sesama manusia. Kepastian hukum merupakan perlindungan yustiabel terhadap tindakan sewenang-wenang dan hal ini berarti seseorang akan dapat memperoleh sesuatu yang diharapkan dalam keadaan tertentu. Masyarakat mengharapkan adanya kepastian hukum, karena adanya kepastian hukum masyarakat akan lebih tertib. Hukum bertugas menciptakan kepastian hukum karena bertujuan mencapai ketertiban masyarakat. ${ }^{22}$ Hakim dalam menjalankan tugasnya bertujuan antara lain menjalankan ketentuan Undang-undang, demi keadilan, serta untuk kepastian hukum. Kebebasan hakim seperti pedang bermata dua, kalau dipergunakan secara tidak wajar, tidak layak, apalagi untuk menyalahgunakan kekuasaan, kebebasan tersebut menjadi sewenang-wenang (arbitrary willekeur). Ketidakwajaran, ketidakpantasan, bahkan penyalahgunaan kekuasaan, tidak selalu terjangkau oleh hukum. ${ }^{23}$ Keadilan diartikan sebagai perbuatan atau perlakuan yang adil. Adil adalah tidak berat sebelah, tidak memihak dan berpihak kepada yang benar. Keadilan adalah tidak merugikan seseorang dan memperlakukan kepada tiap-tiap manusia apa yang menjadi haknya, apabila kedua hal tersebut dijalankan oleh seorang hakim, maka baru dikatakan adil. ${ }^{24}$ UU No. 48 Tahun 2004 tentang Kekuasaan Kehakiman menekankan bahwa hakim wajib menggali, mengikuti, dan memahami nilai-nilai hokum dan rasa keadilan yang hidup dalam masyarakat. Hal ini dimaksudkan agar

22 Sudikno Mertokusumo, Op. Cit., hlm. 58.

23 Bagir Manan, "Peranan Pedoman Tingkah Laku Hakim Sebagai Penjaga Kekuasaan Kehakiman Yang Merdeka", Varia Peradilan Majalah Hukum, Jakarta: Ikahi, Tahun XXIV No. 282 Mei 2009, hlm. 5.

24 H.M. Arsyad Sanusi, "Keadilan Substantif dan Problematika Penegakannya", Varia Pertadilan Majalah Hukum, Tahun XXV No. 288 November 2009, J akarta: Ikahi, hlm. 35. 
putusan hakim sesuai dengan hukum dan rasa keadilan masyarakat". Hakim dilarang menolak untuk memeriksa dan mengadili suatu perkara yang diajukan kepadanya, serta berkewajiban untuk menggali nilai-nilai hukum yang hidup. Sekalipun peraturan tertulis dapat memberikan perasan kepastian hukum yang lebih kuat, namun kepastian hukum terutama berasal dari kepercayaan bahwa hukum tidak diterapkan sewenang-wenang. Hakim sebagai penegak hukum mempunyai tugas dan kewajiban untuk selalu menggali, mengikuti dan memahami nilainilai hukum yang hidup menurut adat setempat. ${ }^{25}$

Setiap orang menginginkan agar rumah tangganya harmonis. Hal ini tertuang dalam UU Perkawinan di mana Pasal 31 ayat (1) mengatur bahwa hak dan kedudukan istri seimbang dengan hak dan kedudukan suami dalam kehidupan rumah tangga dan pergaulan hidup bersama dalam masyarakat. Namun dalam kehidupan sehari-hari tidaklah seindah dengan apa yang telah dirumuskan dalam undang-undang tersebut. Namun, realita yang terjadi bahwa masih banyak dijumpai ketidakseimbangan hak antara laki-laki dan perempuan di masyarakat. Lakilaki sebagai kepala rumah tangga dan mempunyai fisik yang lebih kuat dari perempuan seringkali melakukan tindakan diskriminasi atau penindasan terhadap perempuan. Kondisi ini banyak ditunjang oleh budaya masyarakat Indonesia yang banyak menyimpan pola-pola diskriminasi terhadap perempuan, sehingga perempuan sebagai seorang istri haruslah patuh dan tunduk atas segala perintah suami, dalam arti perempuan telah menjadi istri, maka hidup istri hak seutuhnya suami.

Hak suami dan istri dalam menjalankan rumah tangga diatur dalam UU No. 1 Tahun 1974 Pasal 34 yang menentukan:

1) Suami wajib melindungi istrinya dan memberikaan segala sesuatu keperluan hidup berumah tangga sesuai dengan kemampuannya.

25 F.H. Edy Nugroho, "Keberadaan Hukum Adat Dalam Penegakan Hukum Pidana Indonesia", Gloria J uris, Vol. 8 No. 1 Tahun 2008, Jakarta: F.H. UNIKA Atmajaya, hlm. 45.
2) Istri wajib mengatur rumah tangga sebaik-baiknya.

3) Jika suami atau istri melalaikan kewajibannya masing-masing dapat mengajukan gugatan ke pengadilan.

Istri sebagai ibu rumah tangga bukan berarti harus diam di rumah mengurus rumah tangganya. Istri mempunyai hak untuk mengaktualisasikan dirinya dan menghindari penelantaran dalam rumah tangganya. Hal ini dikarenakan istri mempunyai penghasilan sendiri. Lahirnya UU Perkawinan dan peraturan lain yang terkait, selain karena tuntutan unifikasi hukum dan upaya merespon perkembangan dan tuntutan zaman, juga tidak terlepas dari keinginan dan perjuangan panjang dari perempuan-perempuan Indonesia. Tuntutan kaum perempuan untuk kesetaraan ini banyakj dilatarbelakangi oleh praktik hukum dan sikap masyarakat yang tidak menghargai hak-hak perempuan dalam perkawinan, seperti terjadinya perkawinan paksa dengan alasan ijbaar wali, suami tidak memenuhi hak-hak istri dan anak, poligami semaunya, talak sewenang-wenang dan tidak menghiraukan hak perempuan yang ditalak. ${ }^{26}$

Selanjutnya ditegaskan dalam UU No. 1 Tahun 1974 ayat (1), (2) dan (3):

(1) Hak dan kedudukan istri seimbang dengan hak dan kedudukan suami dalam kehidupan rumah tangga dan pergaulan hidup bersama dalam masyarakat.

(2) Masing-masing pihak berhak melakukan perbuatan hukum.

(3) Suami adalah kepala keluarga dan istri ibu rumah tangga.

Kedudukan perempuan dalam pandangan Islam tidak sebagaimana diduga atau dipraktikan sebagian masyarakat. Ajaran Islam pada hakikatnya memberikan perhatian yang sangat besar serta kedudukan terhormat kepada perempuan. M. Al-Gazali menyebutkan bahwa: ${ }^{27}$

"kalau kita mengembalikan pandang-an ke masa sebelum seribu tahun, maka kita akan menemukan perempuan menikmati

26 Isnawati Rais, "Kedudukan Hukum Perempuan dalam Undang-Undang Perkawinan (UUP)", J urnal Legislasi Indonesia, Jakarta: Ditjen Peraturan PerundangUndangan Kementerian Hukum dan HAM RI, Vol 7 No. 2 Tahun 2010, hlm. 188.

27 Ibid. hlm. 420 
keistimewaan dalam bidang materi dan sosial yang tidak dikenal perempuan di kelima benua. Keadaan mereka ketika itu lebih baik dibandingkan dengan keadaan perempuan barat dewasa ini, asal saja kebebasan dalam berpakaian serta pergaulan tidak dijadikan bahan perbandingan."

Perlindungan hukum tersebut, secara umum diberikan oleh Pasal 28 D UUD 1945 ayat (1) yang mengatur setiap orang berhak atas pengakuan, jaminan, perlindungan dan kepastian hukum yang adil serta perlakuan yang sama di hadapan hukum. Setiap orang di sini menegaskan bahwa baik perempuan maupun laki-laki adalah memiliki hak-hak yang sama di hadapan hukum. Selain itu dalam Pasal 1 ayat (4) UU KDRT, bahwa perlindungan adalah segala upaya yang ditujukan untuk memberikan rasa aman kepada korban yang dilakukan oleh pihak keluarga, advokad, lembaga sosial, kepolisian, kejaksaan, pengadilan atau pelaksana lainnya baik sementara maupun berdasarkan penetapan pengadilan. Hakim, dalam memutuskan suatu kasus, harus senantiasa berorientasi pada penegakan hukum dan keadilan, sehingga putusannya akan dinilai dengan objektif bagi masyarakat umumnya dan khususnya bagi pencari keadilan, apa-lagi di tengah-tengah era refomasi hukum dan trasformasi yang sedang berjalan saat ini, peran dan fungsi hukum semakin ditempatkan sebagai instrument penting dalam mengadakan berbagai perubahan yang direncanakan. ${ }^{28}$

Kedudukan perempuan dalam sistem hukum Indonesia, UUD 1945 dan UU No. 39 Tahun 1999 Tentang HAM telah menegaskan kesetaraan perempuaan dengan laki-laki, namun tidak sedikit produk hukum negara baik di tingkat nasional, propinsi, maupun kota/kabupaten yang berpotensi menim-bulkan diskriminasi terhadap perempuan, seperti di masa awal kemerdekaan, produk hukum di Indonesia di tahun 2000-

28 Heru Susanto, "Peran Hakim Agung Dalam Penemuan Hukum (Reshtsvinbding) dan Penciptaan Hukum (Rechtsschepping) Pada Era Reformasi dan Transformasi", J urnal Hukum Masalah-Masalah Hukum, Vol. 36 No. 2 April-J uni 2007, Semarang: Fakultas Hukum Undip, hlm. 91. an atau pascareformasi 1998, sudah menunjukkan perhatian terhadap perempuan dan kesetaraan gender, akan tetapi potensi diskriminasi tetap ada dan masin dijumpai dalam masyarakat.

Kedudukan perempuan dalam hukum Indonesia sudah dijelaskan secara eksplisit dalam UUD 1945 Pasal 28 D sebagaimana di uraikan di atas. Kesetaraan kedudukan perempuan dan laki-laki tersebut dipertegas dalam UU No. 39 Tahun 1999 Tentang HAM Pasal 3:

(1) Setiap orang dilahirkan bebas dengan harkat dan martabat manusia yangg sama dan sederajat serta dikaruniai akal dan hati nurani untuk hidup bermasyarakat, berbangsan dana bernegara dalam semangat persaudaraan.

(2) Setiap orang berhak atas pengakuan, jaminan, perlindungan dan perlakuan hukum yang adil serta mendapat kepastian hukum dalam semangat di depan hukum.

(3) Setiap orang berhak atas perlindungan hak asasi manusia dan kebebasan manusia, tanpa diskriminasi.

Kemudian Pasal 2 UU HAM menentukan bahwa Negara RI mengakui dan menjunjung tinggi hak asasi manusia dan kebebasan dasar manusia sebagai hak yang secara kondrati melekat pada dan tidak terpi-sahkan dari manusia, yang harus dilindu-ngi, dihormati, dan ditegaskan demi peningkatann martabat kemanusiaan, kesejahteraan, kebahagiaan, dan kecerdasan serta keadilan. Pasal 3 ayat (2) juga menentukan bahwa setiap orang berhak atas perngakuan, jaminan perlindungan dan perlakuan hukum yang adil serta mendapat kepastian hukum dan perlakuan yang sama di depan hukum. Sedangkan ayat (3) merumuskan bahwa setiap orang berhak atas perlindungan hak asasi manusia dan kebebasan dasar manusia tanpa diskriminasi. Pasal 8 merumuskan bahwa perlindungan, pemajuan, penegakan dan pemenuhan hak asasi manusia terutama menjadi tanggung jawab Pemerintah.

Perlindungan hukum bagi pihak berperkara, secara umum, ditegaskan dalam Pasal 17 UU No. 39 Tahun 1999 yang mengatur bahwa setiap orang tanpa diskriminasi berhak untuk 
memperoleh keadilan, dengan mengajukan permohonan pengaduan, dan gugatan, baik dalam perkara pidana, perdata maupun administrasi serta diadili melalui proses peradilan yang bebas dan tidak memihak, sesuai dengan hukum acara yang menjamin pemeriksaan yang objektif oleh hakim yang jujur dan adil untuk memperoleh putusan yang adil dan benar.

UU HAM secara eksplisit mengatur hakhak perempuan yang dalam UU HAM disebutkan sebagai "wanita" yaitu pada Bagian Kesembilan Pasal 45 sampai Pasal 51. Muatan perlindungan hak-hak tersebut antara lain: pertama, hak perempuan adalah bagian dari HAM (Pasal 45); kedua, pengakuan hak politik perempuan(Pasal 46); Ketiga, hak perempuan atas kewarganegaraan(Pasal 47); keempat, hak perempuan atas pendidikan dan pengajaran(Pasal 48); kelima, hak perempuan atas pekerjaan (Pasal 49); keenam, hak perempuan atas kesehatan reproduksi (Pasal 49); ketujuh, hak perempuan atas perbuatan hukum yang mandiri (Pasal 50); dan kedelapan, hak perempuan dalam perkawinan, perceraian, dan pengasuhan anak (Pasal 51). Sementara itu, pada Bagian Menimbang butir a dan b, UU KDRT mengatur bahwa setiap warga negara berhak mendapatkan rasa aman dan bebas dari segala bentuk kekerasan sesuai dengan falsafah Pancasila dan UUD 1945. Berdasarkan penjelasan tersebut, segala bentuk kekerasan, terutama kekerasan dalam rumah tangga merupakan pelanggaran hak asasi manusia dan kejahatan terhadap martabat kemanusiaan serta bentuk diskriminasi yang harus dihapus.

Seorang perempuan, ketika mencari keadilan dan perlindungan, baik dalam proses naming, blaming dan claiming, yakni ketika perempuan mengadukan masalahnya sampai proses penyelesaian perkara dilakukan, perempuan senantiasa mengalami diskriminasi. Perempuan, ketika mengalami kasus kekerasan, merasakan ketidak-adilan yang terjadi pada dirinya (naming). Perempuan kemudian mempersalahkan atau mulai menuntut orang atau pihak yang melakukan kekerasan terhadap dirinya (blaming) dan ketika perempuan mengadukan kasusnya ke pihak ketiga maka perempuan korban mulai berpikir bagaimana cara mereka mencari keadilan (claiming).

\section{Faktor yang Menjadi Hambatan bagi Pihak Is- tri dalam Mengajukan Gugat Cerai di Penga- dilan.}

Kekerasan dalam rumah tangga berbasis gender cenderung sulit dipahami, sehingga sulit pula untuk ditanggulangi secara tuntas. Hal ini dipengaruhi oleh stereotype dan pola pikir masyarakat yang disosialisasi dan telah terinternalisasi, serta ditunrunkan dari generasi ke generasi, seperti posisi dan peran gender (lakilaki dan perempuan) yang berdampak terhadap pandangan mengenai pantas atau tidak pantas, boleh atau tidak bolehnya suatu hal dilakukan oleh laki-laki atau perempuan. ${ }^{29}$ Kenyataan tersebut sampai kapan pihak istri dapat mempunyai kedudukan yang sama haknya dengan suami kalau tidak melalui putusan-putusan pengadilan. Berdasarkan pada asas kedudukan dan persamaan hak antara laki-laki dan perempuan maka sudah selayakanya pihak Pengadilan Agama memberikan keputusan yang adil bagi pihak perempuan atau istri sebagai pihak yang mengajukan gugat cerai. ${ }^{30}$

Tujuan peradilan adalah menegakkan hukum dan keadilan maka hakim harus melakukan beberapa hal. Pertama, Mampu menafsir Undang-undang secara aktual, agar hukum yang diterapkan dilenturkan sesuai dengan kebutuhan perkembangan kondisi, waktu dan tempat, diterapkan sesuai dengan tuntutan kepentingan umum dan kemaslahatan masa sekarang; kedua, berani berperan mencipta hukum baru, dalam hal peraturan perundangan tidak mengatur permasalahan tentang suatu kasus konkreto; ketiga, berani menyingkirkan pasal undangundang yang tidak sesuai lagi dengan kebenaran dan keadilan: keempat, mampu berperan mengadili secara kasuistik, yaitu pengadilan/hakim harus mampu mengadili setiap perkara yang diajukan kepadanya, harus mampu mengadili perkara case by case. Fungsi pengadilan,

\footnotetext{
29 Wahyu Ernaningsih, "Perspektif Gender Dalam UndangUndang Kekerasan Dalam Rumah Tangga", Jurnal IImiah Pusat Studi Wanita Jipswari, Vol. I No. 1 Tahun 2010, Palembang: Unsri, hlm. 173.

30 lbid.
} 
secara teknis, adalah memeriksa, mengadili, dan memutus perkara. Memutus perkara atau sengketa tidak sama dengan menyelesaikan perkara. Suatu putusan hakim ada kemungkinan lebih memperdalam luka hati yang ada dan dapat menimbulkan rasa benci, penasaran atau dendam. Perkara, secara yuridis, telah selesai, tetapi karena salah satu pihak atau bahkan para pihak merasa masih ada gankalan dalam hati. Ketidakpuasan terhadap putusan pengadilan, bahkan bisa melebar kearah tuntutan lain seperti pidana dalam rangka belas dendam tersebut. ${ }^{31}$

Budaya dan ideologi patriarchal baik di dunia barat maupun timur masih sangat mewarnai berbagai aspek kehidupan dan struktur masyarakat yang menciptakan ketimpangan dan ketidakadilan gender, hubungan dan keluarga, teknologi, kewarisan, ekonomi dan masih banyak di bidang lain. Pemerintah Indonesia telah berusaha menerapkan prinsip-prinsip yang dianut konvensi wanita yaitu prinsip-prinsip persamaan substantif, non diskriminasi dan prinsip kewajiban negara dengan mengahrmonisasikannya ke dalam hukum nasional sesuai dengan asas kesetaraan dan keadilan gender.

Berkaitan dengan hal tersebut, kaum perempuan sebagai istri mempunyai hak mengajukan gugat cerai terhadap suaminya, apabila perbuatan ini dianggapnya yang terbaik. Kaum perempuan atau istri, pada sisi lain, sering mengalami hambatan-hambatan dalam hal mengajukan gugat cerainya ke pengadilan, antara lain: pertama, ada ancaman atau intimidasi dari pihak suami, di mana sebagian besar pihak perempuan merasa takut kepada pelaku yang sebagian besar adalah suami dari korban; kedua, menyangkut harga diri dalam kehidupan masyarakat karena apabila pihak istri yang menggugat, image di masyarakat tidak baik; ketiga, faktor budaya. masyarakat masih banyak menilai negatif perempuan yang bercerai; keempat, ketergantungan ekonomi yang begitu besar terhadap suami membuata perempuan

31 Bambang Supriyanto, "Mediasi Dalam Sengketa Hubungan Kerja Terbelenggu Dalam Format Legalistik", Gloria J uris, Vol. 18 No. 2 Tahun 2008, Jakarta: Fakultas Hukum UNIKA Atmajaya, hlm. 21. merasa tidak berdaya menghidupi dirinya sendiri; kelima, pengetahuan yang minim mengenai proses persidangan, pembagian harta gono gini, hak asuh anak dan lain-lain; keenam, perspektif hakim yang masih bias dan cenderung menyalahkan perempuan dalam menyikapi masalah gugat cerai; ketujuh, proses persidangan yang lama dan biaya tertentu dari korban; kedelapan, Kaum perempuan bersikap pasrah pada keadaan menerima segala kenyataan termasuk bentuk perlakuan misalnya kekerasan fisik, maupun mental yang dilakukan suaminya dalam rumah tangga; kesembilan, kaum perempuan belum mempunyai kesadaran akan hak-haknya dan belum berani akan eksistensi dan kompetensinya apabila akan melakukan gugat cerai di pengadilan; kesepuluh, pihak pengadilan sampai saat ini mengakui tidak memiliki daya paksa untuk menekan mantan suami agar menjalankan kewajiban hukum mereka.

\section{Penutup}

Berdasarkan pembahasan tersebut di atas, disimpulkan bahwa faktor-faktor penyebab tingginya gugat cerai di Kota Palembang khususnya di wilayah hukum Pengadilan Agama Palembang dikelompokan berdasarkan urutan teratas antara lain: tidak ada tanggung jawab dari pihak suami, tidak ada keharmonisan, gangguan pihak ketiga, ekonomi, krisis akhlak, kekejaman jasmani, serta poligami tidak sehat/ selingkuh. Bentuk perlindungan hukum bagi pihak perempuan/istri yang mengajukan gugat cerai di Pengadilan Agama selama dalam proses persidangan, dalam sistem hukum Indonesia, mengatur persamaan kedudukan dalam hukum, perlakuan yang sama di depan hukum dan hak memperoleh keadilan sebagaimana diatur dalam Pasal 27 (1), Pasal 28 C, Pasal 28 G, Pasal $38 \mathrm{H}$, Pasal $38 \mathrm{I}$, UUD 1945 pasca amandemen. Demikian juga dalam UU No. 7 tahun 1984 yang merupakan ratifikasi CEDAW dan dimaksudkan untuk menghapus diskriminasi terhadap wanita, serta melindungi hak-hak wanita.

Perlindungan hukum juga diatur dalam Pasal 16 dan Pasal 17 UU KDRT yang mengatur bahwa setiap orang berhak mendapatkan perlindungan dari pihak Kepolisian. Selain itu, 
dalam UU No. 39 Tahun 1999 Tentang HAM, perempuan/ istri mempunyai hak memperoleh keadilan bagi setiap orang (Pasal 17), hak perempuan adalah bagian dari HAM (Pasal 45), hak perempuan atas perbuatan hukum yang mandiri (Pasal 50) dan hak perempuan dalam perkawinan, perceraian, dan pengasuhan anak(Pasal 51).

Sesuai dengan ketentuan Pasal 57 ayat (3) UU No. 3 Tahun 2006 tentang Peradilan Agama bahwa peradilan dilakukan dengan sederhana, cepat dan biaya ringan. Pengadilan Agama Palembang dalam menangani kasus gugat cerai dilakukan dengan asas tersebut. Upaya perdamaian melalui mediasi tetap harus dilakukan sesuai dengan Perma No. I Tahun 2008 tentang Mediasi dan Pasal 82 UU No. 7 Tahun 1989 tentang Upaya perdamaian dalam setiap persidangan perceraian. Dalam hal pihak perempuan merasa terancam dalam persidangan, pihak Pengadilan Agama minta bantuan pihak Kepolisian agar menjaga, melindungi pihak perempuan/ istri da-lam setiap persidangan.

Ada beberapa faktor yang menjadi penghambat bagi pihak perempuan/istri dalam mengajukan gugat cerai di Pengadilan. Pertama, faktor budaya berupa stigma sosial, masyarakat masih banyak yang menilai negatif perempuan yang bercerai, seringkali korban dianggap kurang mampu melayani suami, kurang sabar, kurang pandai mengurus anak dan lain-lain; kedua, ketergantungan ekonomi yang begitu besar terhadap suami membuat perempuan merasa tidak berdaya menghidupi dirinya sendiri; ketiga, pengetahuan yang minim mengenai proses persidangan, pembagian harta gono gini, hak asuh anak dan lain-lain; keempat, perspektif hakim yang masih bias dan cenderung menyalahkan perempuan dalam menyikapi permasalahan gugat cerai; kelima, proses persidangan yang membutuhkan waktu yang lama serta biaya tertentu yang harus dibayar oleh korban; keenam, kaum perempuan/istri bersikap pasrah pada keadaan, menerima segala kenyataan termasuk bentuk perlakuan misalnya kekerasan fisik, maupun mental yang dilakukan suaminya dalam rumah tangga; ketujuh, kaum perempuan belum mempunyai kesadaran akan hak-haknya dan belum berani akan eksistensi dan kom- petensinya apabila akan melakukan gugat cerai di pengadilan; kedelapan, adanya ancaman atau intimidasi dari pihak suami karena sebagian besar pihak perempuan merasa takut kepada pelaku yang sebagian besar adalah suami dari korban; kesembilan, menyangkut harga diri dalam kehidupan ma-syarakat, apabila pihak istri yang menggugat maka image di masyakarat tidak baik; kesepuluh, adanya hak-hak perempuan atau mantan istri dan anak-anak pasca perempuan tidak dengan mudah dieksekusi. Pengadilan Agama sampai saat ini mengakui tidak memiliki daya paksa untuk menekan mantan suami agar menjalankan kewajiban hukum mereka.

\section{Daftar Pustaka}

Ahmad, Sjamsiah. Tentang Gerakan Perempuan dan CEDAW di Indonesia. J akarta: Komnas Perempuan Edisi 4 Maret 2010;

Ernaningsih, Wahyu. "Perspektif Gender dalam Undang-Undang Kekerasan dalam Rumah Tangga". J urnal IImiah Pusat Studi Wanita J ipswari. Vol. I No. 1 Tahun 2010. Palembang: Unsri;

Gusliana. "Penyebab Terjadinya Kekerasan dalam Rumah Tangga (KDRT) yang Dilakukan oleh Suami Terhadap Istri di Kota Pekanbaru". Jurnal Ilmu Hukum. Edisi I No. I, Agustus 2010. Riau: Fakultas Hukum Universitas Riau;

Hartini dan Destri Budi Nugraheni. "Studi tentang Pemutusan Hak-Hak Isteri Oleh Suami Yang Menikah Menurut Hukum Islam Di Daerah Istimewa Yogyakarta". J urnal Mimbar Hukum. No. 42/ X/2002 Tahun 2002. Yogyakarta: Fakultas Hukum UGM;

Ibrahim, Johny. 2008. Teori \& Metodologi Penelitian Hukum Normatif. Malang: Bayu Media Publishing;

Koro, H.M. Abdi. "Tinjauan Hukum Atas Perkawinan Dini dikaitkan dengan Perlindungan Hukum terhadap Anak Di Bawah Umur Dalam Upaya Pengembangan Kualitas Sumber Daya Manusia". Varia Peradilan Majalah Hukum. Tahun XXV No. 2391. Tahun 2010. J akarta: Ikahi;

Manan, Bagir. "Peranan Pedoman Tingkah Laku Hakim Sebagai Penjaga Kekuasaan Kehakiman Yang Merdeka". Varia Peradilan 
Majalah Hukum. Jakarta: Ikahi, Tahun XXIV No. 282 Mei 2009;

Mertokusumo, Sudikno. 1991. Mengenal Hukum (Suatu Pengantar). Yogyakarta: Liberty;

Mujahidin, AM. "Penghapusan Kekerasan Dalam Rumah Tangga (KDRT) Ruang Lingkup Perlindungan Terhadap Anak dan Istri". Varia Peradilan Majalah Hukum Tahun XXV No. 290, Januari 2010, J akarta: Ikahi;

Nugroho, F.H. Edy. "Keberadaan Hukum Adat dalam Penegakan Hukum Pidana Indonesia". Gloria Juris. Vol. 8 No. 1 Tahun 2008. J akarta: F.H. UNIKA Atmajaya;

Rais, Isnawati. "Kedudukan Hukum Perempuan dalam UU Perkawinan (UUP)". J urnal Legislasi Indonesia. Jakarta: Ditjen Peraturan Perundang-undangan Kementerian Hukum dan HAM RI. Vol 7 No. 2 Tahun 2010;

Rangkuti, Ramlan Yusuf. "Pembatasan Usia Kawin dan Persetujuan Calon Mempelai daIam perspektif Hukum Islam". J urnal Hukum Equality, Vol. 13 No. 1. Februari 2008. Medan: Fakultas Hukum USU;
Sanusi, H.M. Arsyad. "Keadilan Substantif dan Problematika Penegakannya", Varia Peradilan Majalah Hukum, Tahun XXV No. 288 November 2009, J akarta: Ikahi;

Supriyadi dan Yulkarnain Harahap. "Perkawinan di Bawah Umur dalam Perspektif Hukum Pidana dan Hukum Islam". Jurnal Mimbar Hukum. Vol. 21 No. 3. Oktober 2009. Yogyakarta: Fakultas Hukum UGM;

Supriyanto, Bambang. "Mediasi Dalam Sengketa Hubungan Kerja Terbelenggu dalam Format Legalistik". Gloria J uris. Vol. 18 No. 2 Tahun 2008. Jakarta: Fakultas Hukum UNIKA Atmajaya;

Susanto, Heru. "Peran Hakim Agung dalam Penemuan Hukum (Reshtsvinbding) dan Penciptaan Hukum (Rechtsschepping) Pada Era Reformasi dan Transformasi", Jurnal Hukum Masalah-Masalah Hukum. Vol. 36 No. 2 April-J uni 2007. Semarang: Fakultas Hukum Undip;

Widyastuti, A Reni. "Peran Hukum dalam Memberikan Perlindungan terhadap Perempuan Dari Tindak Kekerasan di Era Globalisasi". J urnal Mimbar Hukum. Tahun 2009. Yogyakarta: FH UGM. 